\title{
Street connectivity and walking: An empirical study in Londrina-PR
}

\section{Conectividade viária e a caminhada: Um estudo empírico em Londrina-PR}

\author{
Ana Luiza Favarão Leão ${ }^{1}$; Mariana Ragassi Urbano ${ }^{2}$
}

\begin{abstract}
Walkability is emerging as an urban planning guideline that encourages walking, considered the healthiest and most sustainable mean of transportation. Street connectivity, essential for walkable spaces, is commonly measured through Intersection Density (ID). On the other hand, Integration is understood as a more complex measure of connectivity. In Brazil, no study has been identified considering these variables in terms of walkability or sociodemographic variable moderations. The objective of this research is to analyze these connectivity measures' influence on walking, considering sociodemographic covariables in a multiple logistic regression. A case study was conducted in Londrina-PR considering Origin-Destination data of trips $(n=19323)$ and sociodemographic characteristics. Integration was calculated for each street segment in a $1200 \mathrm{~m}$ radius. ID was calculated by zone, considering intersection quantity and area. A multiple logistic regression model was fitted, containing significant covariables. Odds Ratio were analyzed in relation to their theoretical implications. Results indicate that residents of highly connected areas walked more. Both connectivity measures were significant. This suggests that although related, they can capture different aspects of the street network. This study contributes with evidence for the Brazilian context on connectivity through the prism of walkability. Through empiricism, it will be possible to subsidize public policy and urban planning in the creation of walkable spaces.
\end{abstract}

Keywords: Walkability. Space syntax. Intersection density. Logistic regression. Active travel.

\section{Resumo}

A caminhabilidade emerge como uma diretriz de planejamento urbano que incentiva a caminhada, considerada como o meio de transporte mais saudável e sustentável. A conectividade viária, essencial para espaços caminháveis, geralmente é medida por meio da densidade de intersecções (DI). Por outro lado, Integração é entendida como uma medida mais complexa de conectividade. No Brasil, nenhum estudo foi identificado que considere essas variáveis em termos de caminhabilidade ou moderação de variáveis sociodemográficas. $\mathrm{O}$ objetivo desta pesquisa é analisar a influência dessas medidas de conectividade na caminhada, considerando covariáveis sociodemográficas em uma regressão logística múltipla. Foi realizado um estudo de caso em Londrina-PR, utilizando dados de origem-destino de viagens $(n=19323)$ e características sociodemográficas. A Integração foi calculada para cada segmento de via em um raio de $1200 \mathrm{~m}$. A DI foi calculada por zona, considerando a quantidade de intersecções e a área da zona. Um modelo de regressão logística múltipla foi ajustado, contendo covariáveis significativas. As Razões de Chance foram analisadas em relação às suas implicações teóricas. Os resultados indicam que os moradores de áreas altamente conectadas andaram mais. Ambas as medidas de conectividade foram significativas. Isso sugere que, embora relacionadas, elas podem capturar diferentes aspectos da rede de ruas. Este estudo contribui com evidências para o contexto brasileiro sobre conectividade considerando o prisma da caminhabilidade. Por meio do empirismo, será possível subsidiar políticas públicas e planejamento urbano na criação de espaços caminháveis.

Palavras-chave: Caminhabilidade. Sintaxe espacial. Densidade de intersecções. Regressão logística. Deslocamento ativo.

\footnotetext{
${ }^{1}$ Me., Depto. de Arquitetura e Urbanismo, UEL, Londrina, Paraná, Brasil; E-mail: analuiza.favarao@uel.br

${ }^{2}$ Profa. Dra., Depto. de Estatística, UEL, Londrina, Paraná, Brasil; E-mail: mrurbano@uel.br
} 


\section{Introduction}

Walkability, the environmental quality related to how much the built environment encourages or inhibits walking, is emerging as a planning guideline, in the incentive of active travel (GILES-CORTI et al., 2016). Well-planned urban spaces are considered to be more compact and provide economic vitality, environmental sustainability, as well as quality of life for residents (GEHL, 2013; SALLIS et al., 2016). In this sense, considering urban sprawl as a mark of contemporary urban development, the compactness of urban centers is rarely encouraged (FRANK et al., 2019). This pattern of development has been characterized, mainly in US and Australian cities, by low residential density, isolated commercial developments with large parking lots, and mainly low street connectivity (WANG et al., 2016). Such characteristics inhibit active travel, mainly by foot, understood as the healthiest, most sustainable and accessible mean of transportation.

Considering this urban development tendency, the connectivity of the street network has gained acceptance as an important characteristic in the research and creation of sustainable and walkable urban environments (SOUTHWORTH; BEN-JOSEPH, 2003; MARSHALL; GARRICK, 2009; MARSHALL; PIATKOWSKI; GARRICK, 2014). However, metrics for its objective quantification are hardly explored in the literature (MARSHALL; GARRICK, 2012).

As a fundamental measure for walkability, connectivity measures the connection between destinations (KOOHSARI et al., 2016a). The movement in cities occurs through the street network, which in turn directly influences patterns of active travel (GRASSER, 2014). Connected streets promote more direct routes between destinations (FRANK et al., 2010), becoming a prerequisite for increasing pedestrian activity (ELLIS et al., 2015). Such importance is verified in several studies, which indicate consistent associations between walking, especially for transportation, and street connectivity. (OAKES; FORSYTH; SCHMITZ, 2007; BERRIGAN; PICKLE; DILL, 2010; SUGIYAMA et al., 2012).

As a variable, Intersection Density (ID) is the most common measure for quantifying connectivity (ELLIS et $a l ., 2015)$. It simply considers the number of intersections between streets per unit of area analyzed. In walkability indices, metrics composed of several constructs relevant to this urban quality, ID is considered with a greater weight in relation to residential density and mixed land use, for example, indicating its importance. Much of the research conducted on this topic is concentrated in North America, so investigations in culturally and demographically diverse urban environments are necessary (SALLIS et al., 2009).

On the other hand, Space Syntax can be understood as a complex measure of connectivity, focused on the spatial relationship between streets within a network. It seeks to understand the morphological structure of urban environments (HILLIER; HANSON, 1984), proposing that pedestrian movement depends, in large, on the spatial arrangements produced by society. Hillier (1993), one of the proponents of the Space Syntax theory, argues that the street configuration is the primary generator of pedestrian movement. The relationship between the quantitative measures proposed by the theory have showed in several empirical studies, even in Brazil, high correlations with the movement of pedestrians (ZAMPIERI; RIGATTI, 2006; BARROS et al., 2013).

When compared to Intersection Density, integration - a fundamental measure of Space Syntax - considers how streets connect, being more or less accessible among themselves. Thus, a more integrated element of the street network is more accessible, measured in regards to its connectivity, while ID can attribute the same value to different block compositions. Therefore, it is understood that although both measures quantify street connectivity, they possibly measure the urban shape differently (KOOHSARI et al., 2016b).

International research has recently been analyzing such measures of street connectivity and their association with walking, however in Brazil no study has been conducted on the specific analysis of these variables from the perspective of walkability and the moderation of sociodemographic variables (KOOHSARI; KARAKIEWICZ; KACZYNSKI, 2013). Considering the potential of using connectivity parameters for legal and urban planning purposes, in an attempt to guarantee a basic level of connectivity for future urban developments and promote active travel (KNIGHT; MARSHALL, 2015), this article has the main objective to empirically analyze connectivity measures - intersection density and integration - in relation to their effective influence on the walking, also considering sociodemographic covariates, through logistic regression.

\section{Methods}

As the analyzed phenomenon is contemporary and contextual, therefore, inseparable from reality, the Case Study research strategy was adopted (YIN, 2001). As a case, the city of Londrina-PR was selected, mainly due 
to the availability of extremely current and precise data (2020). The City Hall of Londrina, through its Institute for Research and Urban Planning, developed in 2020, in unison with a specialized consultancy, an Origin and Destination (OD) survey. Doing so, the municipality conforms with the no 12587 Federal Law, that establishes national urban mobility policy guidelines. The OD survey was conducted in a sample of 5.131 valid households, distributed across the territory, in such a way as to represent the households in each zone of the city. The database considered here is available at the website of the Institute for Research and Urban Planning, on the mobility plan web-page (https://ippul.londrina.pr.gov.br/).

Initially, 91 zones were proposed dividing the territory in the municipal boundaries. However, for the purposes of this research, only the 84 zones contained within the municipal urban perimeter were considered (Figure 1). All residents of the households, aged 10 years or more, were interviewed in person and individually. Information was obtained on the characterization of the home, socioeconomic status of the family/residents and of the trips made on the business day preceding the interview. The trips were made by all means of transportation, motorized or non-motorized (on foot, by car, motorcycle, taxi, bus, paid ride application, etc). Records of the of origins and destinations of the trips, modals used, schedules and travel times were collected. The total of valid trips obtained are considered as the total sample of this study $(n=19323$ trips).

\section{Sociodemographic Variables}

Among the characteristics collected by the OD survey, the following sociodemographic variables were considered in this study: Family Income, Education of the Head of the Family, Gender and Age. Considering countless studies in the area of walkability and active travel, this selection of social and individual characteristics is justified, being these the most prominent and influential variables in walking levels (CAUWENBERG et al., 2011; VAN CAUWENBERG et al., 2012; DYCK et al., 2015; LUAN; RAMSAY; FULLER, 2019).

\section{Space Syntax}

Space Syntax seeks to describe, through quantitative measures, the configuration of street networks, relationships between public-private space, urban system as a distribution of land uses, social cohesion and exclusion, as well as accessibility and safety (CARVALHO;
Figure 1 - Londrina's urban perimeter and considered zones.

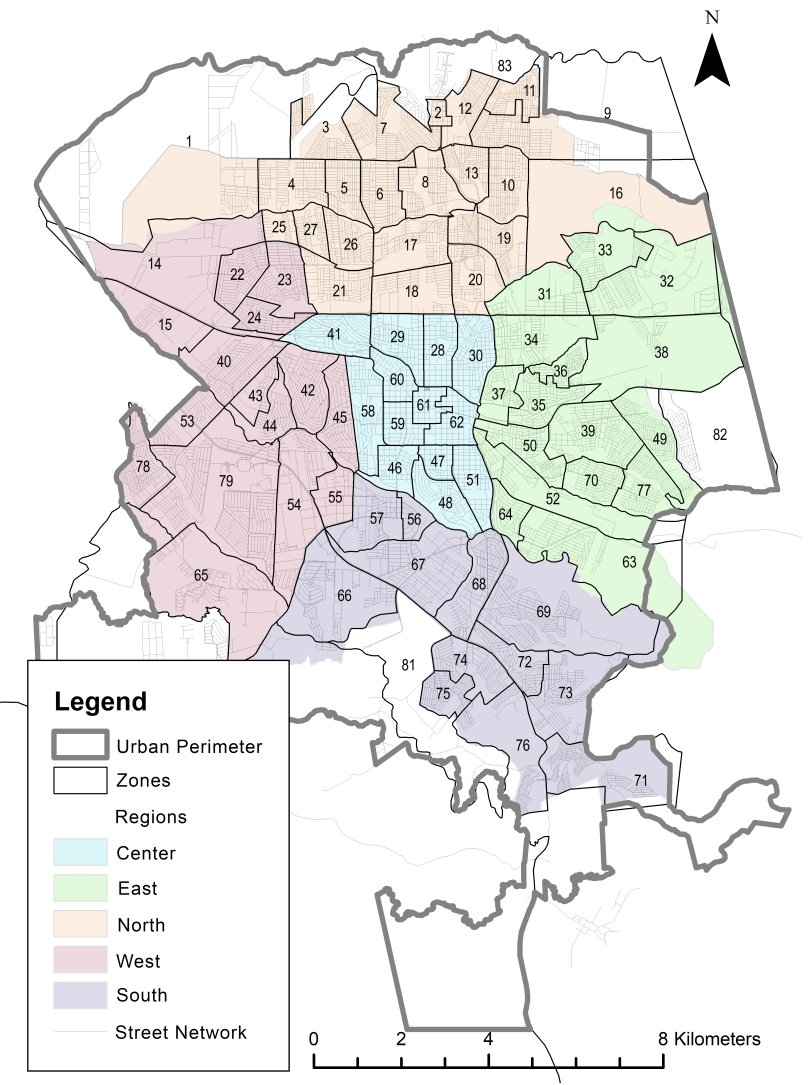

Source: The authors.

SABOYA, 2017). In Space Syntax, urban space is divided into spatial units known as axial lines. These are the largest straight lines capable of covering a whole system of public spaces, possibly being considered as segments - lines with the highest possible straight visibility (HILLIER; HANSON, 1984). The relationships between such elements of a system can be analyzed using the Integration measure, which indicates how "deep", that is, integrated, a network element is from all other elements (HILLIER et al., 1993). The average depth of the i-th element can be calculated by the summation of the depths of the k elements in relation to it, divided by the total number of elements minus one, as given by the equation (1)

$$
M D_{i}=\frac{\sum_{j=1}^{k} d_{i, j}}{(k-1)},
$$

where $M D_{i}=$ Depth of the $i$-th element, $d_{i, j}=$ Depth of line $j$ in relation to the $i$-th element and $k=$ total number of system components.

The most connected lines, closest to all others in a system, are called integrated. On the other hand, the most distant ones are called segregated. The Integration measure can describe the relationship of an element, an abstraction of a street, with all others in a system or only with those 
contained in a predetermined radius. According to Carvalho and Saboya (2017), many studies use a predetermined radius to find the influence of certain factors on smaller scales.

In this study, Integration was calculated based on street centerline data, provided by the City of Londrina and adapted for the representation of segments that were imported into the QGIS software, a free and opensource Geographic Information System (QGIS DEVELOPMENT TEAM, 2020). Through the Space Syntax toolkit (GIL, 2020) and depthmapX (DepthmapX DEVELOPMENT TEAM, 2017), the integration measure was calculated for each street segment within a 1200 meter radius, equivalent to a 15-minute walk (KRONENBERGE; SABOYA, 2019). The configurational characterization of the urban space was conducted through an angular analysis of segments (Figure 2). Subsequently, the average integration of the streets belonging to each zone was calculated, in order to assign an average integration per zone.

Figure 2 - Street Integration at the 1200-meter radius.

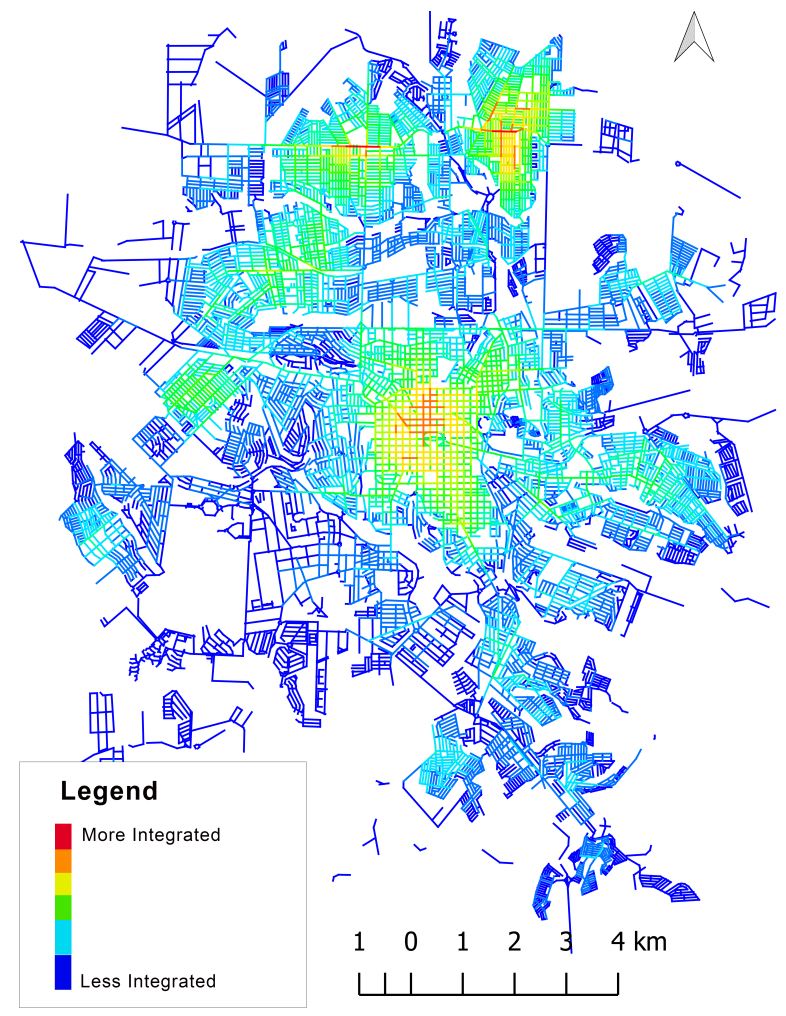

Source: The authors

\section{Intersection Density}

The density of intersections is represented by the ratio between the number of true intersections (between three or more streets) (Figure 3) and the geographical extent of the unit under consideration (FRANK et al., 2010).
Therefore, relevant intersections from Londrina's street network were mapped, using street centerline data in a georeferenced environment. The following equation expresses the ID measure, considering the division of $N$ true intersections contained in a unit and the area in square meters of that same unit, as represented by the equation (2)

$$
\text { ID }=\frac{N \text { true intersections }}{\text { Area in } m^{2}}
$$

Figure 3 - True Intersections mapping from Londrina's street network.

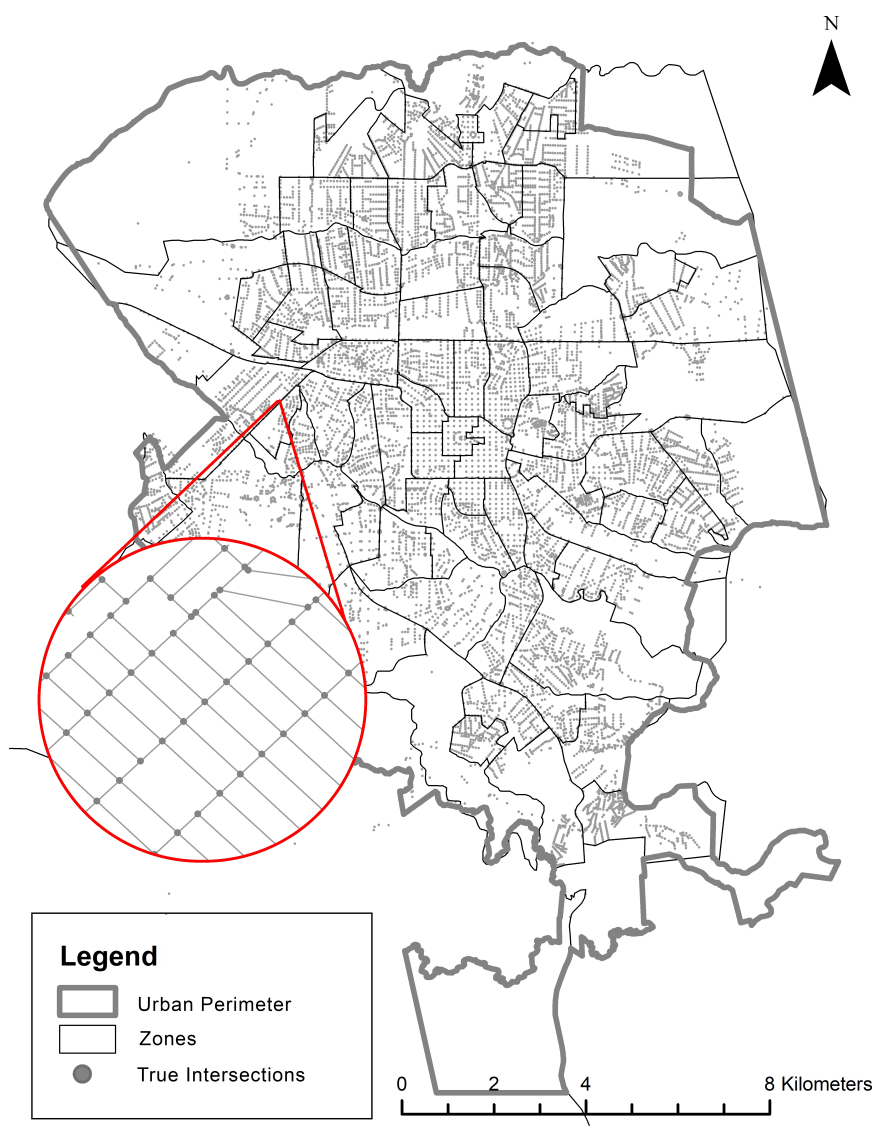

Source: The authors.

After this procedure, the density of intersection by zone was calculated, dividing the number of intersections in each zone by their area, using the software $\mathrm{ESRI}_{\circledR}$ ArcMap 10.6.

\section{Modeling: Logistic Regression}

In logistic regression, the response variable is dichotomous (HOSMER; LEMESHOW, 1989), and the goal is to identify independent variables that influence the outcome. Considering these characteristics, logistic regression was adopted in this study, using data from the OD survey related to the trips, categorized binarily in relation to their modal: was the trip carried out on foot? Yes vs. No. 
The logistic regression was chosen among other kinds of regression (binomial model with other link functions, ordinal regression, multinomial regression or linear regression), because the aim was the comparison and characterization of both groups, and identify similarities and differences among them. Sociodemographic variables were considered as independent variables: Family Income, Education of the Head of the Family, Gender and Age, and the environmental variables representative of street connectivity: Intersection Density and Local Integration r1200 m. All independent variables were also categorized in order to be dichotomous. Logistic regression analysis is relevant as it considers the simultaneous adjustment of different variables, taking into account the effects of confusion between them (HOSMER; LEMESHOW, 1989).

According to Thompson et al. (1998) the risk of the outcome happening versus not happening can be expressed by the estimator called Odds Ratio (OR). This measure has the ability to assess the chance of an individual falling into a category of an explanatory variable, having the condition of interest (in this case, walking), compared to the second category of the same variable (not walking). Thus, it is possible to interpret the chance that an event will happen, in relation to it not happening under the same conditions, as given by the equation (3)

$$
\text { Odds }=\frac{p}{1-p}
$$

This estimator is considered to have good statistical properties (HOSMER; LEMESHOW, 1989), in addition to being easily accessible in statistical packages. ORs can assume values from zero to infinity, however never less than zero or negative (AGRESTI, 2007). Its interpretation depends on both its magnitude and its significance. If ORs are equal to "one", it is interpreted that the factor considered is not a "risk", that is, there is no association between the independent variable and the outcome. If ORs are greater than 1, it is understood that the analyzed variable is considered a "risk", the response variable (in this case of walking or not) is more likely to happen when the characteristic represented also exists. However, if ORs are less than 1 , the analyzed factor can be considered "protective", indicating a negative association, that is: the reduction of the chances of the outcome happening (in case the trip being carried out by foot), regarding the existence of that particular characteristic. In order to define the most appropriate logistic regression model for the data considered, the following steps were considered in preprocessing and modeling:
Initially, a selection of candidate variables for the multiple regression model was carried out through a univariate logistic regression analysis of each covariate with the outcome. Considering $\alpha$ as the Intercept, $\beta$ as a model parameter that represents the regression line inclination and $x$ as an explanatory variable, as given by the equation (4)

$$
\operatorname{logit}[\pi(x)]=\alpha+\beta x .
$$

The conduct of univariate logistic regression indicated the gross ORs presented, accompanied by their respective $95 \%$ confidence intervals. The selection of variables to be included in the multiple model took as a parameter the significance of the covariates in their univariate models, considering those that had a p-value inferior than 0.05 $(5 \%)$ in the maximum likelihood estimator obtained by the Fisher score method.

Second, the multiple logistic regression analysis was conducted, introducing the significant covariates of the univariate logistic regression one by one. From the results obtained, to be presented in the next section, it was not necessary to eliminate any variables from the multiple model, which would result in reprocessing and a new analysis of the adjusted coefficients for the remaining variables through the likelihood-ratio test.

Finally, the model containing all significant covariates at the 5\% significance level, their adjusted Odds Ratios and respective $95 \%$ confidence intervals, were obtained. Thus, the adjusted ORs were analyzed in relation to their theoretical implications. All statistical analyzes were conducted using the R software (R CORE TEAM, 2020).

\section{Results and Discussions}

The percentage of trips made by foot in relation to the total of trips considered is always inferior, as can be observed in Table 1. The percentage of trips made by foot within the classes of variables is distributed in a relatively homogeneous way. It is pointed out that the income variable obtained a discrepant distribution in relation to the representative category of higher income individuals who reported travel.

The adjusted model demonstrates that all variables initially considered contribute significantly to the logistic regression (Table 2). For each trip made by a man 1.49 trips were made by women. Therefore, it can be concluded that considering the presence of other variables, women walked more than men. Although not necessarily consistent with general evidence in the literature, which indicates women as less active than men (DYCK et al., 2015), 
Table 1 - Descriptive analysis of 'risk factors' for walking, sociodemographic and environmental characteristics $(n=19323)$.

\begin{tabular}{|c|c|c|c|}
\hline Variables & Waling trips & Trips by other modals & Total trips \\
\hline \multicolumn{4}{|l|}{ Gender } \\
\hline Woman & $2519(26.0 \%)$ & $7151(73.95 \%)$ & 9670 \\
\hline Man & $1852(19.2 \%)$ & $7801(80.81 \%)$ & 9653 \\
\hline \multicolumn{4}{|l|}{ Age } \\
\hline$<60$ & $3558(21.91 \%)$ & $12680(78.08 \%)$ & 16238 \\
\hline$\geq 60$ & $813(26.35 \%)$ & $2272(73.64 \%)$ & 3085 \\
\hline \multicolumn{4}{|l|}{ Income } \\
\hline$<5 \mathrm{Mw}$ & $4027(24.17 \%)$ & $12633(75.82 \%)$ & 16660 \\
\hline$\geq 5 \mathrm{Mw}$ & $344(12.91)$ & $2319(87.08 \%)$ & 2663 \\
\hline \multicolumn{4}{|l|}{ Education } \\
\hline$<$ High School & $2184(27.39 \%)$ & $5788(72.60 \%)$ & 7972 \\
\hline$\geq$ High School & $2187(19.26 \%)$ & $9164(80.73 \%)$ & 11351 \\
\hline \multicolumn{4}{|l|}{ Integration r1200 } \\
\hline Low & $2847(20.74 \%)$ & $10874(79.25 \%)$ & 13721 \\
\hline High & $1524(27.20 \%)$ & $4078(72.79 \%)$ & 5602 \\
\hline \multicolumn{4}{|l|}{ ID } \\
\hline Low & $1567(18.89 \%)$ & $6727(81.10 \%)$ & 8294 \\
\hline High & $2632(24.93 \%)$ & $7922(75.06 \%)$ & 10554 \\
\hline
\end{tabular}

Source: The authors.

it is conjectured that the result found here is related to the female presence in the workforce. Due to persistent inequalities in the distribution of income by gender, it can be interpreted that there is less possibility for women to own a motor vehicle. Still, it is understood that the fact that women walk more can be related to possible situations of family care, such as taking children to school for example, mostly done by foot. Insecurity in the public space is especially relevant for women (PELCLOVÁ; FRÖMEL; CUBEREK, 2014; DYCK et al., 2015), who are much more susceptible to incivilities or harassment (BASTOMSKI; SMITH, 2017). Women are significantly more susceptible to experiences of insecurity in the public space than men, and even more susceptible to negative impacts on their emotional well-being (BASTOMSKI; SMITH, 2017). Few studies analyze gender equity and the use of public space effectively, considering quantitative aspects that can subsidize public policies (JENSEN et al., 2017). Preserving the right of women to have safe urban environments that support active travel, without fear or precautions to be taken as a result of it (PAIN, 1997), collaborates with gender equity in promoting sustainable behaviors.

For each trip made by an elderly person $(\geq 60$ years), 0.82 trips were made by adults and children.
Therefore, it can be interpreted that the ratio of chances of walking in relation to not walking is significantly higher for the elderly than for individuals under the age of 60 . However, evidence from the literature indicates a decrease in walking levels as age increases (VAN CAUWENBERG et al., 2012). Such studies argue that the urban environment is relevant for the elderly as it increases their functional limitations, considering fear of moving outdoors due to physical barriers such as obstacles, distances or poor maintenance of sidewalks (RANTAKOKKO et al., 2010). The adverse result found here may indicate that among the components of the category " $<60$ years", children, adolescents and adults, some subgroup has different levels of walking, which resulted in a less accurate representation of the differences between adults and the elderly. Broadly speaking, it is understood that in the coming decades the elderly population is expected to increase, and active commuting may play an important role in the prevention of chronic diseases and the burden on public health (CAUWENBERG et al., 2011), thus, this behavior must be preserved and possibly encouraged through interventions in the built environment.

For each trip made by an individual with a higher income (greater than 5 minimum wages), 1.80 trips were made by people of a lower economic level. 
Table 2 - Univariate and multiple Logistic Regression analysis, having 'walking' as an outcome.

\begin{tabular}{|c|c|c|c|c|c|}
\hline Variable & Crude OR & CI 95\% & Adjusted OR & CI 95\% & $p$-value \\
\hline \multicolumn{6}{|l|}{ Gender } \\
\hline Woman & 1.5 & $(1.4,1.61)$ & 1.49 & $(1.39,1.6)$ & $<0.001 * *$ \\
\hline Man & $1.00 *$ & - & 1.00 & - & \\
\hline \multicolumn{6}{|l|}{ Age } \\
\hline$<60$ & 0.76 & $(0.69,0.83)$ & 0.82 & $(0.75,0.91)$ & $<0.001 * *$ \\
\hline$\geq 60$ & 1.00 & - & 1.00 & - & \\
\hline \multicolumn{6}{|l|}{ Income } \\
\hline$<5 \mathrm{Mw}$ & 2.11 & $(1.87,2.37)$ & 1.76 & $(1.55,1.99)$ & $<0.001 * *$ \\
\hline$\geq 5 \mathrm{Mw}$ & 1.00 & - & 1.00 & - & \\
\hline \multicolumn{6}{|l|}{ Education } \\
\hline$<$ High School & 1.56 & $(1.46,1.67)$ & 1.42 & $(1.30,1.50)$ & $<0.001 * *$ \\
\hline$\geq$ High School & 1.00 & - & 1.00 & - & \\
\hline \multicolumn{6}{|l|}{ Integration r1200 } \\
\hline Low & 0.68 & $(0.63,0.73)$ & 0.72 & $(0.67,0.78)$ & $<0.001 * *$ \\
\hline High & 1.00 & & 1.00 & & \\
\hline \multicolumn{6}{|l|}{ ID } \\
\hline Low & 0.7 & $(0.65,0.75)$ & 0.80 & $(0.74,0.86)$ & $<0.001 * *$ \\
\hline High & 1.00 & - & 1.00 & - & \\
\hline
\end{tabular}

$*=1.00$ : reference category; CI 95\%: 95\% Confidence Interval. ** significative at the $\alpha=0.05$ level.

Source: The authors

It is understood that lower income individuals are subject to higher levels of activity, especially in relation to commuting for transportation (AUGUSTO et al., 2017). Evidence shows that the chance of a trip being made by foot is greater for residents of areas where poorer individuals live (OLSEN et al., 2017). Nevertheless, it is important to note that individuals living in poorer areas are more likely to be overweight, have worse levels of general health and higher mortality rates (MACKENBACH et al., 2016). In the same sense, for each trip made by a person with an education level equal to or higher than high school, 1.42 trips were made by people with less education.

International research in the fields of urban planning and public health indicates higher levels of activity performed by residents of neighborhoods with higher levels of street connectivity (HANDY et al., 2002; SAELENS et al., 2003). In this sense, the results found here are consistent: for each trip made by people living in environments with high ID of, 0.76 trips were made by people living in environments with a lower density of intersections. However, it is argued that in Brazil, the metric ID has an interface with social characteristics (REIS et al., 2013). Higher levels of ID have a tendency to be found in peripheral areas, sites of social developments usually characterized by small lots and narrow blocks.
Thus, it is understood that more walking trips being made in areas with a higher ID can be influenced by socioeconomic factors.

For trips made by residents in relation to the average local street integration of the residence area by respondent, the ORs indicate that for each trip made by people living in environments with higher average integration (radius $1200 \mathrm{~m}$ ), 0.72 trips were made by residents of environments with a lower average level of integration. The theory, as proposed by Hillier, coincides with these results, proposing that Space Syntax represents the movement of people through the street network (HILLIER; HANSON, 1984). More integrated streets are more accessible to other streets, potentially attracting more pedestrians, while less integrated, or deeper, streets would attract fewer people (PEPONIS; BAFNA; ZHANG, 2008). Hillier's proposition, in essence, is that the configuration of the streets represents the 'primary generator' of pedestrian movement, integrated streets attract more people because they also attract mixed land use, that is, destinations to be reached (KOOHSARI et al., 2016b). This result is also associated with social issues, where locally highly integrated areas tend to promote the development of local centralities, considering the radius of 1.200 meters as approximately equivalent to a 15 -minute walk. 
The most disadvantaged population, mostly residents of poorly integrated peripheries, has less possibility of accessing infrastructure, further increasing inequalities (KRONENBERGE; SABOYA, 2019) When it comes to the confidence interval estimates for the ORs analyzed here (Figure 4), it is evident that the ranges obtained are very similar, corresponding to not very wide intervals, that is, bound to be relatively accurate.

Figure 4 - Confidence intervals from adjusted Odds Ratios.

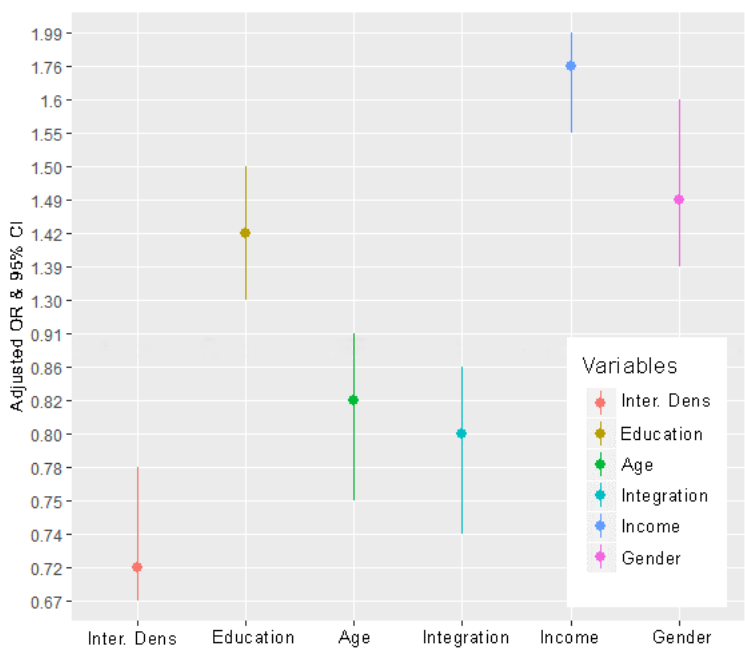

Source: The authors.

\section{Conclusions}

The evidence found here is consistent with previous studies (BADLAND; SCHOFIELD; GARRETT, 2008; BARAN; RODRÍED;GUEZ; KHATTAK, 2008; CERVERO et al., 2009; KOOHSARI et al., 2016b), indicating that people living in areas with well-connected streets are likely to walk more often. Both measures of street connectivity proved to be significantly relevant, both in univariate and multiple logistic regression with the presence of all other variables. This result suggests that although related, they can capture different aspects of the street network related to walking. However, it can be pointed out that although less used in walkability research (KOOHSARI et al., 2016a), the integration measure has the capacity to capture not only a spatial aspect, but also functional and social urban form characteristics. In this sense, considering that the Space Syntax requires only street-related data to be calculated, future research may seek a greater understanding of how to incorporate both measures analyzed here in composed metrics of walkability. Regarding sociodemographic variables, effective actions by public authorities need to consider the existing social gap, as well as gender inequality, so that effective strategies to encourage active mobility can be implemented. Mainly, it can be highlighted that for higher class social groups, which have the tendency to live in more privileged places when it comes to street connectivity, the incentive for utilitarian walking is ideal. On the other hand, lower-class individuals seem to have a tendency to commute by walking, although they do not reside in places that provide infrastructure for such type of transport. Therefore, actions should focus not only on changes at the individual level, but also in considering the creation of urban infrastructure that facilitates existing active behavior, providing a better quality of life for the peripheral population. (BAUMAN et al., 2011).

Although robust, this study has some limitations. Selfreported data is always subject to some kind of bias. The connectivity metrics were calculated aggregated by zone, due to the non-availability of parcel lever data due to respondents' confidentiality issues. The calculation of the metrics for the immediate surroundings of each respondent's residence can possibly correspond to more specific results. In regard to the Space Syntax metric, it must be considered that the aggregation of such systemic measures is not ideal, future studies can explore alternative distribution metrics. The OD survey considered here can be understood as an unbalanced panel dataset, as individuals can report more than one trip. This characteristic may affect statistical procedures and must be explored in other work utilizing Origin-Destination information. Further, it can be pointed out that the generalizing properties of the results found are yet to be researched. Future studies may seek to verify the associations found here in other contexts.

The present study contributes with the limited body of scientific literature existing in the Brazilian context on street connectivity through the prism of walkability. Through empirical evidence such as those presented here, it will be possible to subsidize public policies and urban planning in the creation of walkable spaces that optimize and promote active travel.

\section{Acknowledgments}

To the Coordenação de Aperfeiçoamento de Pessoal de Nivel Superior (CAPES) for the Scholarship.

\section{References}

AGRESTI, A. An introduction to categorical data analysis. 2. ed. New Jersey: John Wiley \& Sons, 2007. 
AUGUSTO, P.; RODRIGUES, F.; MELO, M. P.; ASSIS, M. R.; PALMA, A. Condições socioeconômicas e prática de atividades físicas em adultos e idosos?: uma revisão sistemática. Brazilian Journal of Physical Activity and Health, Londrina, v. 22, n. 3, p. 217-232, 2017.

BADLAND, H. M.; SCHOFIELD, G. M.; GARRETT, N. Travel behavior and objectively measured urban design variables: associations for adults traveling to work. Health \& place, Kidlington, v. 14, n. 1, p. 85-95, mar. 2008.

BARAN, P. K.; RODRÍGUEZ, D. A.; KHATTAK, A. J. Space syntax and walking in a New Urbanist and suburban neighbourhoods. Journal of Urban Design, Abingdon, v. 13, n. 1, p. 5-28, 2008. DOI: https://doi.org/10.1080/13574800701803498

BARROS, A. P. B. G.; MARTÍNEZ, L. M. G.; VIEGAS, J. M. C. B.; SILVA, P. C. M.; HOLANDA, F. R. B. Impacto do desenho da malha viária na mobilidade urbana. Paranoá: cadernos de arquitetura e urbanismo, Brasília, n. 9, p. 11-30, 2013. DOI: https://doi.org/10.18830/issn.16790944.n9.2013.12290

BASTOMSKI, S.; SMITH, P. Gender, fear, and public places: how negative encounters with strangers harm women. Sex Roles, New York, p. 73-88, 2017. DOI: http://dx.doi.org/10.1007/s11199-016-0654-6.

BAUMAN, A.; MA, G.; CUEVAS, F.; OMAR, Z.; WAQANIVALU, T.; PHONGSAVAN, P.; KEKE, K.; BHUSHAN, A. Cross-national comparisons of socioeconomic differences in the prevalence of leisure-time and occupational physical activity, and active commuting in six Asia-Pacific countries. Journal of Epidemiology and Community Health, London, v. 65, n. 1, p. 35-43, 2011. Access in: 13 mar. 2020.

BERRIGAN, D.; PICKLE, L. W.; DILL, J. Associations between street connectivity and active transportation. International Journal of Health Geographics, London, v. 9, n. 1, p. 20, 2010. DOI: https://doi.org/10.1186/1476-072X9-20.

CARVALHO, A.; SABOYA, R. T. A localização residencial em uma cidade vertical?: um estudo sintático em Florianópolis. Revista Brasileira de Gestão Urbana, Curitiba, v. 9 , n. 3 , p. 414-429, 2017.

CERVERO, R.; SARMIENTO, O. L.; JACOBY, E.; GOMEZ, L. F.; NEIMAN, A. Influences of built environments on walking and cycling: Lessons from Bogotá. International Journal of Sustainable Transportation, Philadelphia, v. 3, n. 4, p. 203-226, 2009.
DYCK, V.; CERIN, E.; BOURDEAUDHUIJ, I. De; SALVO, D.; CHRISTIANSEN, L. B.; MACFARLANE, D.; OWEN, N.; MITAS, J.; TROELSEN, J.; AGUINAGAONTOSO, I.; DAVEY, R.; REIS, R.; SARMIENTO, O. L.; SCHO, G.; CONWAY, T. L.; SALLIS, J. F. Moderating effects of age, gender and education on the associations of perceived neighborhood environment attributes with accelerometer-based physical activity?: The IPEN adult study. Health \& Place, Kidlington,v. 36, p. 65-73, 2015. DOI: https://doi.org/10.1016/j.healthplace.2015.09.007.

ELLIS, G.; HUNTER, R.; TULLY, M. A.; DONNELLY, M.; KELLEHER, L.; KEE, F. Connectivity and physical activity?: using footpath networks to measure the walkability of built environments. Environment and Planning B: Planning and Design, London, v. 42, n. 1, p. 1-22, 2015. DOI: https://doi.org/10.1177/0265813515610672.

FRANK, L. D.; IROZ-ELARDO, N.; MACLEOD, K. E.; HONG, A. Pathways from built environment to health?: a conceptual framework linking behavior and exposure-based impacts. Journal of Transport \& Health, Amsterdam, v. 12, p. 319-335, 2019. DOI: https://doi.org/10.1016/j.jth.2018.11.008.

FRANK, L. D.; SALLIS, J. F.; SAELENS, B. E.; LEARY, L.; CAIN, K.; CONWAY, T. L.; HESS, P. M. The development of a walkability index: application to the neighborhood quality of life study. British journal of sports medicine, Loughborough, v. 44, n. 13, p. 924-933, 2010. DOI: https://doi.org/10.1136/bjsm.2009.058701.

GEHL, J. Cidade para pessoas. 2. ed. São Paulo: Editora Perspectiva, 2013.

GIL, J. Space syntax toolkit for QGIS. 2020. Available: <https:/github.com/SpaceGroupUCL/ qgisSpaceSyntaxToolkit>. Access in: 13 mar. 2020.

GILES-CORTI, B.; VERNEZ-MOUDON, A.; REIS, R.; TURRELL, G.; DANNENBERG, A. L.; BADLAND, H.; FOSTER, S.; LOWE, M.; SALLIS, J. F.; STEVENSON, M.; OWEN, N. Urban design , transport, and health 1 City planning and population health?: a global challenge. The Lancet, London, v. 388, n. 10062, p. 2912-2924, 2016. DOI: http://dx.doi.org/10.1016/S0140-6736(16)30066-6.

GRASSER, G. Walkability and Public Health: development of GIS-based indicators of walkability for surveillance and planning purposes in the city of Graz. 2014. Dissertation (Doctor Of Medical Science) - Institute for Social Medicine and Epidemiology, Medical University of Graz, Austria, 2014. 
HANDY, S. L.; BOARNET, M. G.; EWING, R.; KILLINGSWORTH, R. E. How the built environment affects physical activity: views from urban planning. American Journal of Preventive Medicine, New York, v. 23, n. 2, p. 64-73, 2002. Suplement 1. DOI: http://dx.doi.org/10.1016/s0749-3797(02)00475-0

HILLIER, B.; HANSON, J. The social logic of space. Cambridge, UK: Cambridge university press, 1984.

HILLIER, B.; PENN, A.; HANSON, J.; GRAJEWSKI, T.; XU, J. Natural Movement: Or, Configuration and Attraction in Urban Pedestrian Movement. Environment and Planning B: Planning and Design, London, v. 20, n. 1, p. 29-66, 1993. DOI: https://doi.org/10.1068/b200029.

HOSMER, D. W.; LEMESHOW, S. Applied logistic regression. [S. l.]: Wiley Periodicals, 1989.

JENSEN, W. A.; STUMP, T. K.; BROWN, B. B.; WERNER, C. M.; SMITH, K. R. Walkability, complete streets, and gender: who benefits most? Health \& Place, Kidlington, v. 48, p. 80-89, 2017.

KNIGHT, P. L.; MARSHALL, W. E. The metrics of street network connectivity?: their inconsistencies. Journal of Urbanism: International Research on Placemaking and Urban Sustainability, Abingdon v. 8, n. 3, p. 240-258, 2015. DOI: http://dx.doi.org/10.1080/17549175.2014.909515.

KOOHSARI, M. J.; KARAKIEWICZ, J. A.; KACZYNSKI, A. T. Public open space and walking: the role of proximity, perceptual qualities of the surrounding built environment, and street configuration. Environment and Behavior, Beverly Hills, v. 45, n. 6, p. 706-736, 2013. DOI: http://dx.doi.org/10.1177/0013916512440876

KOOHSARI, M. J.; OWEN, N.; CERIN, E.; GILESCORTI, B.; SUGIYAMA, T. Walkability and walking for transport: Characterizing the built environment using space syntax. International Journal of Behavioral Nutrition and Physical Activity, London, v. 13, n. 1, 2016 a. DOI: http://dx.doi.org/10.1186/s12966-016-0448-9.

KOOHSARI, M. J.; SUGIYAMA, T.; MAVOA, S.; VILLANUEVA, K.; BADLAND, H.; GILES-CORTI, B.; OWEN, N. Street network measures and adults' walking for transport: Application of space syntax. Health and Place, Kidlington, v. 38, p. 89-95, $2016 \mathrm{~b}$. DOI: https://doi.org/10.1016/j.healthplace.2015.12.009.
KRONENBERGE, B. C.; SABOYA, R. T.. Entre a servidão e a beira-mar?: um estudo configuracional da segregação socioespacial na área conurbada de florianópolis (ACF), Brasil. urbe. Revista Brasileira de Gestão Urbana, Curitiba, v. 11, p. 1-21, 2019.

LUAN, H.; RAMSAY, D.; FULLER, D. Household income, active travel, and their interacting impact on body mass index in a sample of urban Canadians?: a Bayesian spatial analysis. International Journal of Health Geographics, London, p. 1-10, 2019. DOI: https://doi.org/10.1186/s12942-019-0168-x.

MACKENBACH, J. D.; LAKERVELD, J.; VAN LENTHE, F. J.; BÁRDOS, H.; GLONTI, K.; COMPERNOLLE, S.; DE BOURDEAUDHUIJ, I.; OPPERT, J.-M.; RODA, C.; RUTTER, H.; BRUG, J.; NIJPELS, G. Exploring why residents of socioeconomically deprived neighbourhoods have less favourable perceptions of their neighbourhood environment than residents of wealthy neighbourhoods. Obesity Reviews, Oxford, v. 17, p. 42-52, 2016. DOI: https://doi.org/10.1111/obr.12375

MARSHALL, W. E.; GARRICK, N. W. Community design and how much we drive. The journal of transport and land use, Minneapolis, v. 5, n. 2, p. 5-21, 2012. DOI: https://doi.org/10.5198/jtlu.v5i2.301

MARSHALL, W. E.; PIATKOWSKI, D. P.; GARRICK, N. W. Community design, street networks, and public health. Journal of Transport \& Health, Amsterdam, v. 1, n. 4, p. 326-340, 2014. DOI: http://dx.doi.org/10.1016/j.jth.2014.06.002.

MARSHALL, W.; GARRICK, N. W. Street network types and road safety?: a study of 24 California Cities. Urban Design International, London, apr. 2009.

OAKES, J. M.; FORSYTH, A.; SCHMITZ, K. H. The effects of neighborhood density and street connectivity on walking behavior: The Twin Cities walking study. Epidemiologic Perspectives and Innovations, London v. 4, 2007. DOI: https://doi.org/10.1186/1742-5573-4-16

OLSEN, J. R.; MITCHELL, R.; MUTRIE, N.; FOLEY, L.; OGILVIE, D. Population levels of , and inequalities in, active travel?: a national, cross-sectional study of adults in Scotland. Preventive Medicine Reports, New York, v. 8, p. 129-134, sep. 2017. DOI: http://dx.doi.org/10.1016/j.pmedr.2017.09.008. 
PAIN, R. H. Social Geographies of women's fear of crime. The Royal Geographical Society (with the Institute of British Geographers), London, v. 22, n. 2, p. 231244, 1997.

PELCLOVÁ, J.; FRÖMEL, K.; CUBEREK, R. Genderspecific associations between perceived neighbourhood walkability and meeting walking recommendations when walking for transport and recreation for czech inhabitants over 50 years of age. International Journal of Environmental Research and Public Health, Basel, p. 527-536, 2014

PEPONIS, J.; BAFNA, S.; ZHANG, Z. The connectivity of streets: Reach and directional distance. Environment and Planning B: Planning and Design, London, v. 35, n. 5, p. 881-901, 2008. DOI: http://dx.doi.org/10.3390/ijerph110100527.

QGIS DEVELOPMENT TEAM. QGIS Geographic Information System. 2020. Available: http://qgis.osgeo.org/en/site/. Access in: 13 mar. 2020 .

R CORE TEAM. R: a language and environment for statistical computing. 2020. Available: http://www.rproject.org/. Access in: 13 mar. 2020.

RANTAKOKKO, M.; IWARSSON, S.; HIRVENSALO, M.; LEINONEN, R.; HEIKKINEN, E.; RANTANEN, T. Unmet physical activity need in old age. Journal of the American Geriatric Association, New York, v. 58, p. 707$712,2010$.

REIS, R. S.; FERREIRA HINO, A. A.; RECH, C. R.; KERR, J.; HALLAL, P. C. Walkability and physical activity findings from Curitiba, Brazil. American Journal of Preventive Medicine, New York, v. 45, n. 3, p. 269-275, 2013.

SAELENS, B. E.; SALLIS, J. F.; BLACK, J. B.; CHEN, D. Neighborhood-based differences in physical activity: An environment scale evaluation. American Journal of Public Health, Newark, v. 93, n. 9, p. 1552-1558, 2003. DOI: http://dx.doi.org/10.2105/ajph.93.9.1552

SALLIS, J. F.; BOWLES, H. R.; BAUMAN, A.; AINSWORTH, B. E.; BULL, F. C.; CRAIG, C. L.; SJOSTROM, M.; DE BOURDEAUDHUIJ, I.; LEFEVRE, J.; MATSUDO, V.; MATSUDO, S.; MACFARLANE, D. J.; FERNANDO GOMEZ, L.; INOUE, S.; MURASE, N.; VOLBEKIENE, V.; MCLEAN, G.; CARR, H.;
HEGGEBO, L. K.; TOMTEN, H.; BERGMAN, P. Neighborhood environments and physical activity among adults in 11 countries. American Journal Of Preventive Medicine, New York, v. 36, n. 6, p. 484-490, jun. 2009.

SALLIS, J. F.; CERIN, E.; CONWAY, T. L.; ADAMS, M. A.; FRANK, L. D.; PRATT, M.; SALVO, D.; SCHIPPERIJN, J.; SMITH, G.; CAIN, K. L.; DAVEY, R.; KERR, J.; LAI, P.-C.; MITAS, J.; REIS, R.; SARMIENTO, O. L.; SCHOFIELD, G.; TROELSEN, J.; VAN DYCK, D.; DE BOURDEAUDHUIJ, I.; OWEN, N. Physical activity in relation to urban environments in 14 cities worldwide: a cross-sectional study. LANCET, Oxford, v. 387, n. 10034, p. 2207-2217, 2016.

SOUTHWORTH, M.; BEN-JOSEPH, E. Streets and the shaping of towns and cities. Washington, DC: Island Press, 2003.

SUGIYAMA, T.; NEUHAUS, M.; COLE, R.; GILESCORTI, B.; OWEN, N. Destination and route attributes associated with adults' walking: a review. Medicine And Science In Sports And Exercise, Madison, v. 44, n. 7, p. 1275-1286, jul. 2012.

THOMPSON, M. L.; MYERS, J. E.; KRIEBEL, D. Prevalence odds ratio or prevalence ratio in the analysis of cross sectional data?: what is to be done?? Occupational and Environmental, London, v. 55(4), p. 272-277, apr. 1998. DOI: http://dx.doi.org/10.1136/oem.55.4.272.

UCL - SPACE SYNTAX LAB. DepthmapX: visual and spatial network analysis software. 2017. Available: https://github.com/SpaceGroupUCL/depthmapX/. Access in: 13 mar. 2020.

VAN CAUWENBERG, J.; BOURDEAUDHUIJ, I. De; MEESTER, F.; DYCK, D. Van; SALMON, J.; CLARYS, P.; DEFORCHE, B. Relationship between the physical environment and physical activity in older adults?: A systematic review. Health \& Place, Kidlington, v. 17, n. 2, p. 458-469, 2011. DOI: http://dx.doi.org/10.1016/j.healthplace.2010.11.010.

VAN CAUWENBERG, J.; VAN HOLLE, V.; SIMONS, D.; DERIDDER, R.; CLARYS, P.; GOUBERT, L.; NASAR, J.; SALMON, J.; DE BOURDEAUDHUIJ, I.; DEFORCHE, B. Environmental factors influencing older adults' walking for transportation: a study using walkalong interviews. International Journal of Behavioral $\mathrm{Nu}$ trition and Physical Activity, London, v. 9, n. 1, p. 11, jul. 2012. DOI: http://dx.doi.org/10.1186/1479-5868-9-85. 
WANG, Y.; CHAU, C. K.; NG, W. Y.; LEUNG, T. M. ZAMPIERI, F. L.; RIGATTI, D. A atividade comercial A review on the effects of physical built environment attributes on enhancing walking and cycling activity levels within residential neighborhoods. Cities, London, v. 50, p. 1-15, 2016. como potencializadora do movimento de pedestres nos centros urbanos: um modelo baseado em redes neurais artificiais. In: COLÓQUIO INTERNACIONAL SOBRE COMÉRCIO E CIDADE, 11., 2006, Porto Alegre. Anais

YIN, R. K. Estudo de caso: planejamento e métodos. 2. [... ]. Porto Alegre: [s. n.], 2006.

ed. São Paulo: Bookman Companhia Editora, 2001. 